\title{
ANALISIS PERBEDAAN PRESTASI DAN MOTIVASI BELAJAR ANTARA PEMBELAJARAN QUANTUM TEACHING DENGAN PEMBELAJARAN KONVENSIONAL PADA MATA DIKLAT SIKLUS AKUNTANSI
}

\author{
Santi Apriliani Alifa Tanggamasari \\ SMPN 5 Batu \\ santiapril@gmail.com
}

\begin{abstract}
This research aims to know about the differences between quantum teaching and conventional methode on student's achievement and motivation at SMK Islam Batu. This research is quasy experiment. Sample of this research are 104 students and sampling methode uses purposive sampling. Data collections use questianarre. Data analysis to examine the hypothesis is $t$-test Independent Samples. The result shows that motivation and student's achievement increase using quantum theaching.
\end{abstract}

Keywords: Quantum teaching, student's achievement, Convention methode, motivation

Abstrak: Penelitian ini bertujuan untuk mendapatkan gambaran secara obyektif tentang apakah terdapat perbedaan prestasi dan motivasi yang signifikan antara pembelajaran quantum teaching dengan pembelajaran konvensional di SMK Islam Batu. Jenis penelitian ini merupakan penelitian eksperimen semu. Sampel penelitian sebanyak 104 siswa dan metode penyampelan menggunakan teknik purposive sampling. Pengumpulan data menggunakan angket/kuesioner. Analisis data yang digunakan untuk menguji hipotesis adalah T-Test Independent Samples.

Kata kunci: Quantum Teaching, Prestasi belajar , Pembelajaran Konvensional, Motivasi,

Perkembangan Ilmu Pengetahuan dan Teknologi telah membawa perubahan hampir di semua aspek kehidupan manusia, dimana berbagai permasalahan hanya dapat dipecahkan dengan upaya penguasaan dan peningkatan Ilmu Pengetahuan dan Teknologi. Peningkatan terhadap penguasaan Ilmu Pengetahuan dan Teknologi tidak lepas dari peran dunia pendidikan. Hal ini berarti sistem pendidikan nasional harus dikembangkan agar lebih terarah, serasi dan relevan dengan tuntutan kebutuhan dan selaras dengan perkembangan Ilmu Pengetahuan dan Teknologi. 
Salah satu usaha yang dapat dilakukan untuk maksud di atas adalah dengan memperbarui sistem pembelajaran. Menurut Setyosari (1990:1) yang dimaksud dengan sistem pembelajaran adalah gabungan dari unsur-unsur dalam proses belajar mengajar yang sengaja dirancang untuk mencapai tujuan yang telah ditetapkan sebelumnya dan pelaksanaannya diawasi. Dalam hal ini, guru merupakan komponen pendidikan yang berperan sebagai perancang (planner), pelaksana (executor), dan penilai (evaluator) sistem pembelajaran. Usaha pembaharuan sistem pembelajaran ini terutama ditujukan untuk meningkatkan produktivitas dan efisiensi dalam proses belajar mengajar.

Menurut DePorter (2002:3) proses belajar mengajar merupakan fenomena yang komplek. Segala sesuatunya berarti, mulai dari setiap kata, pikiran dan asosiasi, serta sampai sejauh mana lingkungan itu diubah, presentasi, dan rancangan pengajaran, sejauh itu pula proses belajar berlangsung. Hal ini berarti agar tujuan pembelajaran dapat tercapai secara optimal, setiap unsur dalam pembelajaran harus dilaksanakan secara beriringan. Untuk mencapai tujuan pembelajaran tersebut, peranan guru tidak hanya sebatas memberikan bahan ajar di dalam kelas. Guru perlu mendalami keadaaan siswa-siswanya dengan berusaha memahami berbagai kebutuhan yang diperlukan oleh siswanya. Salah satu kebutuhan siswa adalah mendapatkan pengajaran dengan model pembelajaran yang sesuai dengan materi sehingga siswa menjadi tertarik untuk belajar.

Banyak model pembelajaran yang dapat digunakan sebagai alternatif dalam kegiatan pembelajaran. Dalam hal ini, kemampuan guru dalam menggunakan model pembelajaran yang disesuaikan dengan kondisi lingkungan, karakteristik siswa, dan materi pembelajaran sangat diperlukan. Kegiatan belajar mengajar dapat berlangsung dengan adanya interaksi antara guru dan siswa. Interaksi di sini tidak hanya interaksi yang berupa dialog, tetapi interaksi yang lebih bersifat mempengaruhi agar siswa tersebut mau belajar. Dapat dikatakan bahwa guru adalah fasilitator, pengarah atau penuntun yang mempengaruhi suasana agar suasana tersebut kondusif untuk siswa belajar.

Siswa mau belajar juga karena ada faktor pendorong atau motivasi baik dari dalam maupun dari luar. Menurut Risk dalam Rohani (2004:11) motivasi adalah usaha yang disadari oleh pihak guru untuk menimbulkan motif-motif pada diri peserta didik atau pelajar yang menunjang kegiatan ke arah tujuan-tujuan belajar. Keberhasilan suatu pengajaran sangat dipengaruhi oleh adanya motivasi. Motivasi penting bagi proses 
belajar karena motivasi menggerakkan organisme, mengarahkan tindakan, dan memilih tujuan yang dirasa paling berguna dalam kehidupan individu. Motivasi tidak dapat diketahui secara langsung. Motivasi dalam diri seseorang dapat kita interpretasikan dari tingkah lakunya. Dalam hal ini, hasil tingkah laku siswa dalam kegiatan belajar dapat diketahui dari hasil atau prestasi belajar yang dicapai pada saat evaluasi pengajaran yang biasanya dilakukan setelah proses pembelajaran tersebut.

Oleh karena pentingnya kemampuan guru untuk menimbulkan motivasi pada diri siswa agar siswa mempunyai prestasi yang optimal, maka diperlukan suatu model atau pendekatan pembelajaran yang mampu meningkatkan motivasi dan prestasi belajar. Berdasarkan observasi awal yang dilakukan pada SMK Islam Batu menunjukan bahwa siswa program studi akuntansi, kurang memiliki motivasi untuk belajar. Selain itu jumlah jam pelajaran siklus akuntansi yang lama yaitu 4 x 45 menit setiap pertemuannya membuat siswa cepat merasa bosan dengan rutinitas yang ada.

Salah satu model pembelajaran untuk meningkatkan motivasi belajar siswa adalah pembelajaran quantum teaching. Menurut DePorter (2002:12) quantum teaching adalah salah satu pendekatan pengajaran yang memberikan petunjuk spesifik untuk menciptakan lingkungan belajar yang efektif, merancang kurikulum, menyampaikan isi, dan memudahkan proses belajar. Dalam quantum teaching, guru sangat diharapkan sebagai aktor yang mampu memainkan berbagai gaya belajar anak, mengorkestrakan kelas, menghipnotis kelas dengan daya tarik, dan menguatkan konsep ke dalam diri anak.

Prinsip penerapan quantum teaching adalah "Bawalah Dunia Siswa ke Dunia Guru, dan antarkan Dunia Guru ke Dunia Siswa”. Inilah asas utama yang merupakan alasan dasar di balik semua strategi, model dan keyakinan quantum teaching. Hal ini menunjukkan, betapa pengajaran dengan quantum teaching tidak hanya menawarkan materi yang mesti dipelajari siswa. Untuk menerapkan asas ini, pertama-tama guru harus membangun jembatan autentik memasuki kehidupan murid dengan cara mengaitkan pelajaran dengan sebuah peristiwa, pikiran atau perasaan yang diperolah dari kehidupan rumah, sosial, atletik, musik, seni, rekreasi, atau akademis siswa. Setelah kaitan itu terbentuk, pengajar dapat membawa siswa ke dunia pengajar, dan memberikan mereka pemahaman pengajar mengenai isi dunia itu. Disinilah kosakata baru, model mental, rumus, dan lain-lain dibeberkan. Akhirnya, dengan pengertian yang 
lebih luas dan penguasaan lebih mendalam ini, siswa dapat membawa apa yang dipelajari ke dalam dunia siswa dan menerapkannya pada situasi baru.

Penerapan model Quantum teaching harus memperhatikan unsur - unsur sebgai berikut yaitu (i) konteks; (ii) suasana yang memberdayakan; (iii) landasan yang kokoh; (iv) lingkungan yang mendukung; (v) rancangan pengajaran yang dinamis; (vi) isi. Penyusunan kerangka rancangan belajar quantum teaching didasarkan pada istilah TANDUR, $\mathrm{T}$ (Tumbuhkan, artinya menumbuhkan minat belajar siswa dengan memuaskan, baik yang dilakukan dengan memberikan pertanyaan ataupun materi pengantar); A (Alami, artinya menciptakan atau mendatangkan pengalaman umum yang dapat dimengerti semua pelajar); N (Namai, Artinya menyediakan kata kunci, konsep, model, rumus, strategi dalam mengkonkretkan konsep yang abstrak sehingga siswa mudah dalam mempelajari konsep; D (Demonstrasikan, artinya menyediakan kesempatan bagi pelajar untuk menunjukkan bahwa mereka tahu. Dalam demonstrasi ini guru memberikan peragaan yang melibatkan siswa dan guru mampu menjelaskan konsep yang didemonstrasikan dengan runtut dan jelas; U (Ulangi, artinya menunjukkan kepada pelajar bagaimana cara mengulangi konsep materi yang telah dijelaskan dengan cara membuat model permainan lain, sehingga dengan variasi pembelajaran yang lain siswa akan lebih tahu dan jelas terhadap konsep yang telah dipelajari serta menegaskan kepada siswa "Aku tahu bahwa aku memang tahu"); R (rayakan, artinya pengakuan guru terhadap penyelesaian, partisipasi, dan perolehan ilmu pengetahuan dan ketrampilan oleh siswa akan meningkatkan motivasi belajar dan rasa percaya diri untuk belajar yang lebih baik) (DePorter, 2002:8-11).

Model pembelajaran quantum teaching dapat meningkatkan motivasi disebabkan karena dengan menggunakan model ini, guru dituntut untuk menciptakan lingkungan belajar yang efektif, dengan cara menggunakan unsur yang ada pada siswa dan lingkungan belajarnya melalui interaksi yang terjadi di dalam kelas. Interaksi serta proses pembelajaran yang tercipta akan berpengaruh besar sekali terhadap efektivitas dan antusiasme belajar pada peserta didik. Penerapan model pembelajaran ini menyebabkan guru akan lebih mencintai dan lebih berhasil dalam memberikan materi serta lebih dicintai anak didik karena guru mengoptimalkan berbagai metode. Hal ini berarti motivasi siswa untuk belajar juga akan bertambah. 
Motivasi adalah seni yang merangsang perhatian pada murid apabila tidak memiliki perhatian, atau yang belum dirasakan oleh murid atau menyempurnakan perhatian yang sudah ada supaya menjadi perbuatan yang dikehendaki masyarakat (Mustaqim dan Wahid, 1991:66). Ada beberapa strategi yang bisa digunakan oleh guru untuk menumbuhkan motivasi belajar siswa, sebagai berikut: (i) Menjelaskan tujuan belajar ke peserta didik. Pada permulaan belajar mengajar seharusnya terlebih dahulu seorang guru menjelaskan mengenai Tujuan Instruksional Khusus yang akan dicapainya kepada siwa. Makin jelas tujuan maka makin besar pula motivasi dalam belajar; (ii) Hadiah. Berikan hadiah untuk siswa yang berprestasi. Hal ini akan memacu semangat mereka untuk bisa belajar lebih giat lagi. Di samping itu, siswa yang belum berprestasi akan termotivasi untuk bisa mengejar siswa yang berprestasi; (iii) Saingan/kompetisi. Guru berusaha mengadakan persaingan di antara siswanya untuk meningkatkan prestasi belajarnya, berusaha memperbaiki hasil prestasi yang telah dicapai sebelumnya; (iv) Pujian. Sudah sepantasnya siswa yang berprestasi untuk diberikan penghargaan atau pujian. Tentunya pujian yang bersifat membangun; (v) Hukuman. Hukuman diberikan kepada siswa yang berbuat kesalahan saat proses belajar mengajar. Hukuman ini diberikan dengan harapan agar siswa tersebut mau merubah diri dan berusaha memacu motivasi belajarnya; (vi) Membangkitkan dorongan kepada anak didik untuk belajar. Strateginya adalah dengan memberikan perhatian maksimal ke peserta didik; (vii) Membentuk kebiasaan belajar yang baik; (viii) Membantu kesulitan belajar anak didik secara individual maupun kelompok; (xi) Menggunakan metode yang bervariasi; (x) Menggunakan media yang baik dan sesuai dengan tujuan pembelajaran. Berdasarkan landasan teori yang telah dikemukakan diatas maka pengembangan hipotesis penelitian ini dapat dirumuskan sebagai berikut:

$\mathrm{H}_{1}$ : Ada perbedaan prestasi belajar yang signifikan antara pembelajaran Quantum Teaching dengan pembelajaran konvensional.

$\mathrm{H}_{2}$ : Ada perbedaan motivasi belajar yang signifikan antara pembelajaran Quantum Teaching dengan pembelajaran konvensional. 


\section{METODE}

Penelitian ini termasuk dalam penelitian eksperimen semu (Quasi Eksperimental). Jenis eksperimental semu yang digunakan adalah rancangan pre test-post test pada kelompok tak ekuivalen. Rancangan tersebut berbentuk seperti berikut:

Tabel 1. Rancangan penelitian

\begin{tabular}{|l|l|l|l|}
\hline Kelompok & Pre Test & Perlakuan & Post Test \\
\hline $\mathrm{E}$ & $\mathrm{O}_{1}$ & $\mathrm{X}$ & $\mathrm{O}_{2}$ \\
$\mathrm{~K}$ & $\mathrm{O}_{1}$ & -- & $\mathrm{O}_{2}$ \\
\hline
\end{tabular}

\section{Keterangan :}

$\mathrm{E}=$ Kelompok Eksperimen

$\mathrm{K}=$ Kelompok Kontrol

$\mathrm{X}=$ Pembelajaran Quantum Teaching

O1 = Tes kemampuan awal (Pre Test)

$\mathrm{O} 2=$ Tes kemampuan akhir (Post Test $)$

Dalam rancangan ini, kelompok eksperimen merupakan kelompok yang mendapat perlakuan X. Perlakuan $\mathrm{X}$ adalah penerapan pendekatan quantum teaching dalam pengajaran. Sedangkan kelompok kontrol adalah kelompok yang tidak mendapat perlakuan. Hal ini tidak berarti kelas kontrol tidak menerima pengalaman sama sekali, akan tetapi diajar dengan menggunakan metode konvensional. Pada kedua kelompok dilakukan pre test dan juga post test.

Populasi dari penelitian ini adalah siswa SMK Islam Batu jurusan akuntansi yang berjumlah 246 siswa. Sampel yang digunakan dalam penelitian ini adalah siswa kelas X akuntansi baik kelas X AK 1 maupun kelas X AK 2. Pemilihan sampel dengan menggunakan purposive sampling. Untuk menganalisis ada tidaknya perbedaan prestasi dan motivasi belajar siswa antara pembelajaran quantum teaching dengan pembelajaran konvensional, digunakan uji independent sample $\mathrm{t}$ - test.

\section{HASIL DAN PEMBAHASAN}

\section{Hasil}

Data kemampuan awal siswa dalam penelitian ini diperoleh dari pemberian tes (pre test) kepada kelompok siswa yang menjadi sampel penelitian, yaitu kelas kontrol dan kelas eksperimen. Yang terpilih menjadi kelas kontrol adalah siswa kelas 1 AK 2 
dengan jumlah siswa 51 orang. Kelas 1 AK 1 terpilih menjadi kelas eksperimen dengan jumlah siswa sebanyak 53 orang. Hasil pre test kelas kontrol dan kelas eksperimen dapat dilihat pada tabel 2 .

Tabel 2. Hasil pre test kelas kontrol dan eksperimen

\begin{tabular}{|l|l|l|}
\hline \multirow{2}{*}{ Statistik } & Kemampuan Awal \\
\cline { 2 - 3 } & Kelas Kontrol & Kelas Eksperiment \\
\hline Jumlah siswa & 51 & 53 \\
\hline Mean & 27,4118 & 28,1887 \\
\hline SD & 11,73060 & 12,31643 \\
\hline T - Test & 0,329 & \\
\hline Signifikansi & 0,743 & \\
\hline
\end{tabular}

Pengujian hipotes dilakukan dengan menggunakan uji t yang sebelumnya dilakukan terlebih dahulu uji normalitas dan homogenitas. Berikut hasil uji normalitas adalah sebagai berikut : dari hasil uji one-sample kolmogorov-smirnov test yang telah dilakukan, dapat diketahui bahwa nilai Asymp. Sig. adalah 0,575. Jadi, signifikansi $0,575>0,05$. Dengan demikian dapat disimpulkan bahwa distribusi nilai pre test adalah normal. Hasil pengujian homogenitas menunjukan nilai $\mathrm{F}=0,047$ dengan tingkat signifikansi sebesar 0,829. Dengan demikian signifikansi 0,0829 >0,05 yang berarti bahwa kedua varians sama atau homogen.

Dari tabel 2 dapat dilihat nilai rata-rata kemampuan awal kelaskontrol 27,4118 lebih rendah dari nilai rata-rata kemampuan awal kelas eksperimen 28,1887. Namun perbedaan ini tidak terlalu besar. Hal ini terbukti pada uji beda dengan menggunakan $T$ Test dimana jika signifikansi $<0,05$ maka terdapat perbedaan kemampuan awal kelas kontrol dengan kelas eksperimen. Dari uji t yang telah dilakukan diketahui bahwa harga t sebesar 0,329 dengan tingkat signifikansi 0,743 yang berarti bahwa signifikansi 0,743 $>0,05$. Jadi tidak terdapat perbedaan yang signifikan antara kemampuan awal kelas kontrol dengan kelas eksperimen. Sehingga dapat dinyatakan bahwa kemampuan awal kelas kontrol dan kelas eksperimen adalah sama. 
Hasil post test kelas kontrol dan kelas eksperiment dapat dilihat pada tabel 3.

Tabel 3. Hasil Post Test Kelas Kontrol dan Eksperimen

\begin{tabular}{|l|l|l|}
\hline \multirow{2}{*}{ Statistik } & Kemampuan Awal \\
\cline { 2 - 3 } & Kelas Kontrol & Kelas Eksperiment \\
\hline Jumlah siswa & 51 & 53 \\
\hline Mean & 51,5882 & 73,5472 \\
\hline SD & 17,22228 & 13,37271 \\
\hline T - Test & 0,7279 & \\
\hline Signifikansi & 0,0000 & \\
\hline
\end{tabular}

Hasil uji normalitas menunjukan bahwa nilai Asymp. Sig. adalah 0,410. Jadi, signifikansi $0,410>0,05$. Dengan demikian dapat disimpulkan bahwa distribusi nilai post tes adalah normal. Sedangkan hasil uji homogenitas menunjukan nilai $F=3,624$ dengan tingkat signifikansi sebesar 0,060. Dengan demikian signifikansi 0,060 > 0,05 yang berarti bahwa kedua varians sama atau homogen. Dari tabel 3 dapat dilihat nilai rata-rata kemampuan akhir kelas kontrol adalah 51,5882 dengan standar deviasi 17,22228. Sedangkan nilai rata - rata kemampuan akhir kelas eksperimen adalah 73,5472 dengan standar deviasi 13,37271. Selain itu, berdasarkan uji t yang telah dilakukan diketahui harga $\mathrm{t}=0,7279$ dengan signifikansi sebesar 0,000. Hal ini menunjukkan ada perbedaan prestasi belajar antara kelas kontrol dengan kelas eksperimen.

Tabel 4. Hasil uji prestasi belajar

\begin{tabular}{|l|l|l|l|l|l|l|}
\hline t-test for Equality of Means \\
\hline $\mathrm{T}$ & $\mathrm{df}$ & $\begin{array}{l}\text { Sig. } \\
\text { tailed })\end{array}$ & $\begin{array}{l}\text { Mean } \\
\text { Difference }\end{array}$ & $\begin{array}{l}\text { Std error } \\
\text { Difference }\end{array}$ & $\begin{array}{l}\text { 95\% Confidence } \\
\text { Interval of the } \\
\text { Difference }\end{array}$ \\
\cline { 3 - 7 } & & & & Lower & Upper \\
\hline-7.279 & 102 & .000 & -21.95893 & 3.01695 & -27.94303 & -15.97484 \\
\hline
\end{tabular}

Hasil uji t independent sample menunjukkan nilai t sebesar 7,279 dengan tingkat signifikansi 0,000. Dengan demikian signifikansi $0,000<0,050$. Berdasarkan dasar pengambilan keputusan penerimaan dan penolakan hipotesis, dapat disimpulkan bahwa terdapat perbedaan yang signifikan antara prestasi kelas kontrol dengan kelas eksperimen dimana rata-rata prestasi belajar kelas kontrol lebih rendah dibanding dengan prestasi belajar kelas eksperimen. 
Tabel 5. Hasil uji beda motivasi belajar siswa

\begin{tabular}{|l|l|l|l|l|l|l|}
\hline \multicolumn{2}{|c|}{-test for Equality of Means } \\
\hline $\mathrm{t}$ & $\mathrm{df}$ & $\begin{array}{l}\text { Sig. } \\
\text { tailed })\end{array}$ & $(2$ & $\begin{array}{l}\text { Mean } \\
\text { Difference }\end{array}$ & $\begin{array}{l}\text { Std error } \\
\text { Difference }\end{array}$ & \multicolumn{2}{l|}{$\begin{array}{l}\text { 95\% Confidence } \\
\text { Interval of the } \\
\text { Difference }\end{array}$} \\
\cline { 3 - 7 } & & & & Lower & Upper \\
\hline-6.469 & 102 & .000 & -5.76471 & .89112 & -7.53224 & -3.99717 \\
\hline
\end{tabular}

Hasil uji t independent sample menunjukkan harga t sebesar 6,469 dengan tingkat signifikansi 0,000. Dengan demikian signifikansi $0,000<0,050$. Berdasarkan dasar pengambilan keputusan penerimaan dan penolakan hipotesis, dapat disimpulkan bahwa terdapat perbedaan yang signifikan antara motivasi kelas kontrol dengan kelas eksperimen dimana rata-rata motivasi belajar kelas kontrol lebih rendah dibanding dengan motivasi belajar kelas eksperimen.

\section{Pembahasan}

Perbedaan Prestasi Belajar Siswa antara Pembelajaran Quantum Teaching dengan Pembelajaran Konvensional

Hasil uji hipotesis dengan menggunakan uji t menunjukkan adanya perbedaan rata-rata prestasi belajar antara kelas kontrol dengan kelas eksperimen setelah diberikan perlakuan yang berbeda. Dimana rata-rata prestasi belajar kelas kontrol sebesar 51,59 dan rata-rata prestasi belajar kelas eksperimen sebesar 73,55. Hal ini berarti rata-rata prestasi kelas kontrol lebih rendah dibanding dengan rata-rata prestasi kelas eksperimen. Perbedaan prestasi belajar yang dalam hal ini dinilai dari segi kemampuan kognitif siswa disebabkan perbedaan model pembelajaran yang digunakan di dua kelas, kelas kontrol menggunakan model pembelajaran konvensional sedangkan kelas eksperimen menggunakan pembelajaran quantum teaching.

Perbedaan pembelajaran quantum teaching dan pembelajaran konvensional terletak pada tahap pembelajarannya. Dalam pembelajaran Quantum teaching terdapat enam tahap yang masing-masing tahap dirancang agar siswa merasa senang dan tidak bosan dalam mengikuti pelajaran. Sedangkan dalam pembelajaran konvensional, pembelajaran dilakukan dengan memberikan ceramah kemudian siswa mengerjakan latihan soal dengan berkelompok. Dalam pembelajaran quantum teaching, agar siswa tidak merasa bosan dan kegiatan pembelajaran menjadi efektif, maka salah satu metode 
yang digunakan adalah permainan. Melalui permainan, siswa termotivasi untuk dapat menyelesaikan permainan dengan baik dan secara tidak langsung siswa akan lebih mengingat hasil dari pembelajaran, karena mereka menemukan sendiri inti dari pelajaran tersebut.

Berdasarkan hasil penelitian, dapat disimpulkan bahwa prestasi belajar siswa dengan mengunakan pembelajaran quantum teaching lebih baik dibandingkan dengan pembelajaran konvensional. Hasil penelitian ini sejalan dengan penelitian sebelumnya yaitu penelitian yang telah dilakukan oleh Suryatiningsih (2005) yang menunjukkan bahwa pembelajaran quantum teaching dapat meningkatkan prestasi belajar siswa dalam mata pelajaran Biologi.

\section{Perbedaan Motivasi Belajar Siswa antara Pembelajaran Quantum Teaching dengan Pembelajaran Konvensional}

Hasil uji hipotesis dengan menggunakan uji t menunjukkan adanya perbedaan rata-rata motivasi belajar antara kelas kontrol dengan kelas eksperimen setelah diberikan perlakuan yang berbeda. Dimana rata-rata motivasi belajar kelas kontrol sebesar 40,23 dan rata-rata motivasi belajar kelas eksperimen sebesar 46,00. Hal ini berarti rata-rata motivasi kelas kontrol lebih rendah dibanding dengan rata-rata prestasi kelas eksperimen. Selain itu, berdasarkan hasil penelitian, rata-rata motivasi belajar siswa kelas eksperimen sebesar 46 berada pada rentang nilai 45 - 58 dan pada kriteria tinggi. Sedangkan rata-rata motivasi belajar siswa kelas kontrol sebesar 40,23 berada pada rentang 31 - 44 dan pada kriteria cukup tinggi. Hal ini menguatkan hasil uji hipotesis bahwa motivasi belajar siswa kelas eksperimen lebih tinggi jika dibandingkan dengan motivasi belajar kelas kontrol.

Motivasi belajar ini meliputi motivasi intrinsik dan ekstrinsik. Motivasi intrinsik meliputi rasa ingin tahu, kebiasaan belajar, dan kemauan atau minat belajar. Sedangkan motivasi ekstrinsik meliputi motivasi untuk mendapatkan pujian, motivasi untuk bersaing dengan teman, cara mengajar guru, tujuan belajar, dan pengelolaan kelas. Berdasarkan hasil penelitian diketahui bahwa sebesar 54,72\% siswa kelas eksperimen berpendapat bahwa motivasi belajar setelah mendapat pembelajaran quantum teaching berada pada kriteria tinggi. Dimana 55\% motivasi siswa berasal dari motivasi ekstrinsik dan $45 \%$ berasal dari motivasi intrinsik. Sedangkan untuk siswa kelas kontrol sebesar 
76,47\% siswa berpendapat bahwa motivasi belajar dengan pembelajaran konvensional berada pada kriteria cukup tinggi. Dimana 38,4\% motivasi siswa berasal dari motivasi intrinsik dan $61,6 \%$ berasal dari motivasi ekstrinsik.

\section{DAFTAR RUJUKAN}

DePorter, Bobbi, dkk. 2002. Quantum Teaching: Mempraktekkan QuantumLearning Di Ruang-Ruang Kelas. Bandung : Kaifa

Rohani, Ahmad. 2004. Pengelolaan Pengajaran. Jakarta : Rineka Cipta

Setyosari, Punaji. 1990. Pengajaran Modul. Malang : Proyek Operasi dan Perawatan Fasilitas IKIP Malang

Wahib, Abdul dan Mustaqim. 1991. Psikologi Pendidikan. Jakarta : Rineka Cipta 